'Department of Cardiology, Instituto Nacional del Torax. Santiago, Chile. ${ }^{2}$ Department of Internal Medicine, Universidad de Chile. Santiago, Chile.

${ }^{3}$ Department of Cardiology, Hospital Militar de Santiago. Santiago, Chile.

${ }^{4}$ Department of Cardiology, Hospital Dr Luis Tisné Brousse. Santiago, Chile.

${ }^{5}$ Department of Cardiology, Hospital del Salvador. Santiago, Chile.

anterventional Cardiology Fellowship Program. Universidad de Chile. Santiago, Chile. ${ }^{b}$ Cardiology Fellowship Program. Universidad de Chile. Santiago,

Conflict of interest: The authors declare no conflicts of interest.

Funding: none

Recibido el 28 de diciembre de 2020, aceptado el 13 de abril de 2021.

Corresponding author: Pabla Catado Villarroel Instituto Nacional del Tórax, José Manuel Infante \#717, Providencia. Santiago, Chile. pablacataldov@gmail.com

\section{Consequences of COVID-19 pandemic on myocardial infarction reperfusion therapy and prognosis}

\author{
PABLA CATALDO ${ }^{1,2, a, c}$, FERNANDO J. VERDUGO ${ }^{3, c}$, CAMILA BONTA $^{3, b, c}$, \\ CHRISTIAN DAUVERGNE ${ }^{1,2, \mathrm{c}}$, ALFONSO GARCÍA ${ }^{2, \mathrm{acc},}$ \\ MANUEL MÉNDEZ ${ }^{1, \mathrm{c}}$, POLENTZI URIARTE ${ }^{1, \mathrm{c}}$, FERNANDO PINEDA $^{1, \mathrm{c}}$, \\ MANUEL DUARTE ${ }^{4, c}$, RAÚL SUED ${ }^{4, c}$, PABLO FUICA $^{5, \mathrm{c}}$, \\ GONZALO TORRES ${ }^{5, \mathrm{c}}$, JORGE SANDOVAL ${ }^{1,3, \mathrm{c}}$
}

\section{ABSTRACT}

Background: The coronavirus disease (COVID-19) pandemic affected the prompt diagnosis and treatment of Acute myocardial infarction (AMI). Aim: To characterize the clinical profile of patients with AMI during the COVID-19 pandemic, comparing them with a historical cohort. Material and Methods: A case-control study of 96 patients with AMI transferred to a high-volume percutaneous coronary intervention (PCI) hospital between March and July 2020, and a historical cohort of 269 patients transferred during the same period in 2019. Results: When comparing patients transferred during the pandemic with those of the historical cohort, the former were younger ( $63 \pm 12$ vs $68 \pm 12$ years, $p<0.01$ ), had a higher frequency of hypertension ( $66 v s 45 \%, p<0.01$ ) and of smoking (40\% vs $25 \%, p<0.01$ ). Also, during COVID-19 outbreak a higher proportion of patients had ST-elevation AMI consulting $>12$ hours from the onset of symptoms (44 vs $0 \%, p<0.01$ ), a higher median door-to-device time (4 vs 3 hours, $p<0.01$ ), a higher use of primary percutaneous coronary intervention ( $97 v s 71 \%, p<0.01$ ), and higher frequencies of cardiogenic shock $(20 \mathrm{vs} 4 \%, p<0.01)$ and mechanical complications ( $10 \%$ vs $2 \%, p<0.01$ ). Patients during COVID pandemic had a higher thirty-day overall ( $20 \mathrm{vs} 1.4 \%, p<0.01$ ) and cardiovascular mortality ( 13 vs $1 \%, p<0.01)$. During the outbreak, $40 \%$ of patients had positive COVID-19 status, which was a predictor for thirty-day overall mortality (Risk ratio 2.90; 95\% confidence intervals 1.14-7.36). Conclusions: During the pandemic patients with AMI exhibited delays in consultations and treatment, higher morbidity, and increased mortality. COVID-19 positivity was associated to worse thirty-day overall survival.

(Rev Med Chile 2021; 149: 672-681)

Key words: Cardiac Catheterization; COVID-19; Myocardial Infarction; Percutaneous Coronary Intervention.

\section{Consecuencias de la pandemia COVID-19 en la reperfusión y pronóstico del infarto de miocardio}

Antecedentes: La pandemia COVID-19 afectó el tratamiento oportuno del infarto agudo de miocardio (IAM). Objetivo: Caracterizar el perfil clínico de pacientes con IAM durante la pandemia COVID-19 y compararlos con una 
cohorte histórica. Pacientes y Métodos: Estudio caso-control de 96 pacientes con IAM transferidos a un hospital de alto volumen de intervención coronaria percutánea (ICP) entre marzo julio de 2020 y una cohorte histórica de 269 pacientes transferidos en el mismo período de 2019 ( $n=269)$. Resultados: $A l$ comparar los pacientes transferidos durante pandemia y la cohorte histórica, los primeros eran más jóvenes ( $63 \pm 12$ y $68 \pm 12$ años respectivamente, $p<0,01$ ), tenían una mayor frecuencia de hipertensión (65.6 y $45.1 \%$ respectivamente, $p<0,01)$ y tabaquismo $(39,6$ y 25,1\% respectivamente, $p<0,01)$. También tuvieron una consulta $>12 \mathrm{~h}$ desde iniciados sintomas de IAM con elevación $S T$ (44,4 y 0\% respectivamente, $p<0,01)$, una mediana de tiempo puerta-guía mayor (4 y 3 horas respectivamente, $p<0,01$ ), un mayor uso de ICP primaria (97 y $71 \%$ respectivamente, $p<0,01$ ), mayor frecuencia de shock cardiogénico $(19,8$ y 4,1\% respectivamente, $p<0.01)$ y complicaciones mecánicas $(10,4$ y $1,7 \%$ respectivamente, $p<0,01)$. A treinta dias, los primeros tuvieron mayor mortalidad general $(19,8$ y $1,4 \%$ respectivamente $p<0.01)$ y cardiovascular (12,5 y 1,4\% respectivamente, $p<0,01)$. Durante la pandemia, $40 \%$ de los pacientes presentó positividad para COVID-19, siendo un factor predictivo de mortalidad general (razón de riesgo 2,90; intervalos de confianza 95\% 1,14-7,36). Conclusiones: Durante la pandemia, hubo retrasos en tiempos de consulta $y$ tratamiento y mayor morbimortalidad del IAM. La positividad de COVID-19 se asoció a peor sobrevida general a treinta días.

Palabras clave: Cateterismo Cardíaco; Infecciones por Coronavirus; Infarto del Miocardio; Intervención Coronaria Percutánea.

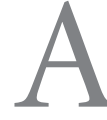
cute myocardial infarction (AMI) constitutes a major cause of morbidity-mortality in Chile; being responsible for $7.5 \%$ of deaths in 20181. During the past decades, morbidity-mortality have considerably declined due to timely reperfusion therapy $y^{2,3}$. Martinez et al. described a 30 -day mortality rate of $8.1 \%$ for AMI patients undergoing percutaneous coronary intervention (PCI) in Chile ${ }^{3}$.

Due to the coronavirus disease 2019 (COVID-19) pandemic, healthcare systems have undergone significant strains, including expansion of intensive care units, cancellation of outpatient visits and procedures ${ }^{4}$. Furthermore, in attempts to reduce viral transmission, stay-at-home campaigns and lockdowns have been established. A deferral in elective procedures was recommended by several cardiovascular societies ${ }^{4,5}$. In Chile, a reduction of around $65 \%$ of interventional cardiology procedures has been reported during the COVID-19 outbreak 6 .

Patients with cardiovascular diseases have been recognized at increased risk of severe illness when infected with SARS-CoV-2. Unfortunately, factors like the restructuring of healthcare systems may cause "collateral damage" to patients with cardiovascular diseases. Despite uncertainties regarding the optimal reperfusion strategy for ST-elevation myocardial infarction (STEMI) during COVID-19 outbreak, international societies have reaffirmed the recommendation for PCI as standard of care for STEMI when provided in a timely fashion. ${ }^{5}$ Nonetheless, international groups report a decline in hospital admissions due to acute cardiovascular diseases ${ }^{7-13}$.

The aim of this study was to characterize the clinical profile, treatment, and outcome of patients with AMI during the coronavirus disease (COVID-19) pandemic, and to compare these variables with a historical cohort at a tertiary cardiac center in Chile.

\section{Patients and Methods}

We performed a case-control study, between March $3^{\text {rd }}$ and July $15^{\text {th }} 2020$, including all patients with STEMI and non-ST elevation myocardial infarction (NSTEMI) transferred to the cardiac catheterization laboratory of Instituto Nacional del Torax, a high-volume PCI center (700 PCI 
per year). Our center does not have an emergency department, patients undergoing AMI are transferred from two nearby hospitals and 20 primary care emergency services. Our center was not dedicated exclusively to COVID-19 attention during the outbreak. The target beneficiary population remained unchanged. Referrals for AMI during the same period of 2019 were reviewed as historical control. We considered March $3^{\text {rd }}, 2020$ as the starting point of COVID-19 outbreak in Chile. The study protocol was approved by the Servicio de Salud Metropolitano Oriente Ethics Committee.

Clinical registries from the cardiac catheterization laboratory were reviewed for assessment of demographics, comorbidities, clinical presentation, and troponin results. STEMI, NSTEMI and AMI with non-obstructive coronary artery disease (MINOCA) were defined according to the fourth definition of myocardial infarction ${ }^{14}$. Symptom onset-to-first medical contact (S-to-FMC) time is defined as the time interval from patient-reported chest discomfort onset to the time of first medical attention in patients with STEMI. Late presentation was defined as S-to-FMC $\geq 12$ hours in patients with STEMI. Door-to-device (D-to-D) time was defined by the interval between initial medical attention and successful wire crossing during primary PCI (excluding patients undergoing systemic fibrinolysis).

COVID-19 positive (C19(P)) status was defined by positive throat swab for SARS-COV-2 by reverse transcription-polymerase chain reaction (RT-PCR), in patients undergoing cardiac catheterization during the COVID-19 outbreak. COVID-19 negative $(\mathrm{C} 19(\mathrm{~N}))$ status was defined by negative RT-PCR during the index hospitalization.

Conventional angiography was performed with a minimum of three views for the left coronary artery and two for the right coronary artery. Intracoronary thrombi were defined by the presence of a filling defect with either a total occlusion with irregular distal margins and post injection contrast retention, or a partial occlusion circumferentially outlined by contrast medium at angiography ${ }^{15}$. Multi-vessel coronary artery disease (CAD) was defined by at least two epicardial coronary arteries with atherosclerotic stenoses of significant severity. PCI indication followed current international guidelines and recommendations ${ }^{4}$.

Cardiovascular deaths, non-cardiovascular deaths, and no-reflow at coronary angiography were defined according to academic research consortium-2-consensus ${ }^{16}$. Ventricular septal rupture, acute mitral regurgitation, and left ventricular free wall rupture are part of the spectrum of mechanical complications after AMI. Left ventricular ejection fraction (LVEF) was addressed through ventriculography when available or transthoracic echocardiography performed during the index hospitalization. Significant systolic dysfunction was defined by LVEF $\leq 40 \%$.

The Civil Registry Database was reviewed to obtain survival status, in September 2020.

\section{Statistical analysis}

Continuous data are expressed as mean \pm standard deviation or median and interquartile range, while categorical data as absolute number and percentage. Categorical data were compared using Pearson $\chi^{2}$ test. Comparison of continuous data between groups at baseline was assessed through unpaired T-test or Mann-Whitney U according to normality. Non-parametric median analyses were performed. Thirty-day survival was addressed through Kaplan-Meier curves and log-rank analysis. Cox logistic regressions were performed to establish relative risk of overall and cardiovascular mortality associated to COVID-19 status. Statistical significance was assumed at a value of $\mathrm{P}<0.05$. Analyses were performed with IBM SPSS Statistics 20.0 (IBM Corp, USA).

\section{Results}

Baseline characteristics are shown in Table 1. Compared to the same period of 2019, during the COVID-19 pandemic there was a $67.5 \%$ reduction in referrals for AMI, $60.5 \%$ for STEMI and 71.8\% for NSTEMI. Demographic characteristics were similar between groups. Regarding cardiovascular risk factors, a higher burden of hypertension and smoking was observed in 2020 ( $\mathrm{p}<0.01)$. Among the studied population during the outbreak, 39 patients had positive RT-PCR for SARS-CoV-2 (40.6\%).

We observed a similar distribution in referrals for STEMI-NSTEMI ( $\mathrm{p}=0.09$ ). In patients with STEMI, there was an increase in average S-to-FMC between both periods ( $\mathrm{p}<0.01)$, and 20 patients had a late presentation during 2020 
Table 1. Baseline clinical and periprocedural characteristics of patients with AMI according to year

\begin{tabular}{|c|c|c|c|}
\hline & $\begin{array}{l}\text { Control group } \\
\quad(n=295)\end{array}$ & $\begin{array}{l}\text { Pandemic group } \\
\quad(n=96)\end{array}$ & $\mathbf{P}$ \\
\hline \multicolumn{4}{|l|}{ Demographics } \\
\hline Age - years & $68 \pm 12$ & $63 \pm 12$ & $<0.01$ \\
\hline Male - number (\%) & $191(64.7)$ & $69(71.9)$ & 0.20 \\
\hline Hypertension - number (\%) & $133(45.1)$ & $63(65.6)$ & $<0.01$ \\
\hline Diabetes - number (\%) & $112(38.0)$ & $38(39.6)$ & 0.78 \\
\hline Smoker - number (\%) & $74(25.1)$ & $38(39.6)$ & $<0.01$ \\
\hline \multicolumn{4}{|l|}{ Index event } \\
\hline STEMI - number (\%) & $114(38.6)$ & $45(46.9)$ & 0.15 \\
\hline S-to-FMC - hours* & $3.6 \pm 2.0$ & $22.3 \pm 31.7$ & $<0.01$ \\
\hline Median S-to-FMC time (IQR) - hours* & $3.0(2.0-5.0)$ & $6.0(2.0-24.0)$ & 0.15 \\
\hline STEMI late presentation - number (\%) * & $0(0)$ & $20(44.4)$ & $<0.01$ \\
\hline Systemic thrombolysis - number (\%) * & $14(12.3)$ & $5(11.1)$ & 1.00 \\
\hline MINOCA - number (\%) & $1(0.3)$ & $29(30.2)$ & $<0.01$ \\
\hline Multivessel disease - number (\%) & $73(24.7)$ & $33(34.4)$ & 0.07 \\
\hline Left main coronary disease - number (\%) & $11(3.7)$ & $8(8.3)$ & 0.07 \\
\hline Intracoronary thrombi - number (\%) & $35(11.9)$ & $33(34.4)$ & $<0.01$ \\
\hline Thrombus aspiration - number (\%) & $4(3.5)$ & $4(8.9)$ & 0.11 \\
\hline Primary $\mathrm{PCI}$ - number (\%) * & $111(97.3)$ & $32(71.1)$ & $<0.01$ \\
\hline Median D-to-D time (IQR) - hourst & $3.0(2.0-4.0)$ & $4.0(3.0-7.8)$ & $<0.01$ \\
\hline No-reflow - number (\%) * & $1(0.9)$ & $8(17.8)$ & $<0.01$ \\
\hline Cardiogenic shock presentation - number (\%) & $12(4.1)$ & $19(19.8)$ & $<0.01$ \\
\hline Intra-aortic balloon pump - number (\%) * & $1(0.9)$ & $5(11.1)$ & $<0.01$ \\
\hline LVEF - \% & $48 \pm 12$ & $46 \pm 13$ & 0.07 \\
\hline LVEF $\leq 40 \%-$ number $(\%)$ & $77(26.1)$ & $36(37.5)$ & 0.03 \\
\hline Maximal hs-cTnl - pg/ml & $4990 \pm 5007$ & $8250 \pm 7755$ & $<0.01$ \\
\hline
\end{tabular}

* In patients with STEMI. † In patients with STEMI, excluding thrombolysis.

$(\mathrm{p}<0.01) .48 \%$ of patients with NSTEMI had S-to-FMC $>24$ hours in 2020, compared to $4.4 \%$ during 2019 ( $\mathrm{p}<0.01)$. No significant differences regarding performance of systemic thrombolysis prior to coronary angiography for STEMI were detected. Reperfusion criteria were observed in $79 \%$ of cases undergoing systemic thrombolysis, with no significant differences between years. With reference to diagnostic coronary angiography findings, patients had no major differences regarding finding of CAD or left main coronary artery disease. There was a higher prevalence of MINOCA, coronary thrombosis (CT) burden and cardiogenic shock (CS) during the COVID-19 outbreak $(\mathrm{p}<0.01)$.

A decrease in primary PCI procedures was detected in patients with STEMI $(\mathrm{p}<0.01)$. Delays in median D-to-D time were observed in 2020 $(\mathrm{p}<0.01)$, as well as higher rates of no-reflow phenomena $(\mathrm{p}<0.01)$. Significant systolic dysfunction was more prevalent in patients with AMI during 2020 ( $\mathrm{p}=0.032$ ). Patients with AMI during 2020 exhibited greater maximal high-sensitivity troponin values $(p=0.001)$. Of note, incidence of mechanical complications increased in patients with AMI during COVID-19 outbreak ( $\mathrm{p}<0.01)$, mainly ischemic mitral regurgitation (Table 2). Concordantly, a higher use of intra-aortic balloon pump was also seen in STEMI patients $(\mathrm{p}<0.01)$.

Significant differences in 30-day overall survival and cardiovascular survival were observed at 30 days of follow-up in patients with AMI between these time periods $(\mathrm{p}<0.01)$ (Figure $1 \mathrm{~A}-\mathrm{B})$. During COVID-19 outbreak, the 30-day cardiovascular survival rate for STEMI and NSTEMI was $75.6 \%$ and $97.9 \%$, respectively. 
Table 2. Outcomes of patients with acute myocardial infarction

\begin{tabular}{|lccc|}
\hline & $\begin{array}{c}\text { Control group } \\
(\mathbf{n = 2 9 5 )}\end{array}$ & $\begin{array}{c}\text { Pandemic group } \\
(\mathbf{n}=\mathbf{9 6})\end{array}$ & P \\
\hline Overall deaths within 30 days - number (\%) & $4(1.4)$ & $19(19.8)$ & $<0.01$ \\
Cardiovascular deaths within 30 days - number (\%) & $4(1.4)$ & $12(12.5)$ & $<0.01$ \\
Mechanical complications - number (\%) & $5(1.7)$ & $10(10.4)$ & $<0.01$ \\
Acute ischemic mitral regurgitation - number (\%) & $3(1.0)$ & $9(9.4)$ & $<0.01$ \\
\hline
\end{tabular}
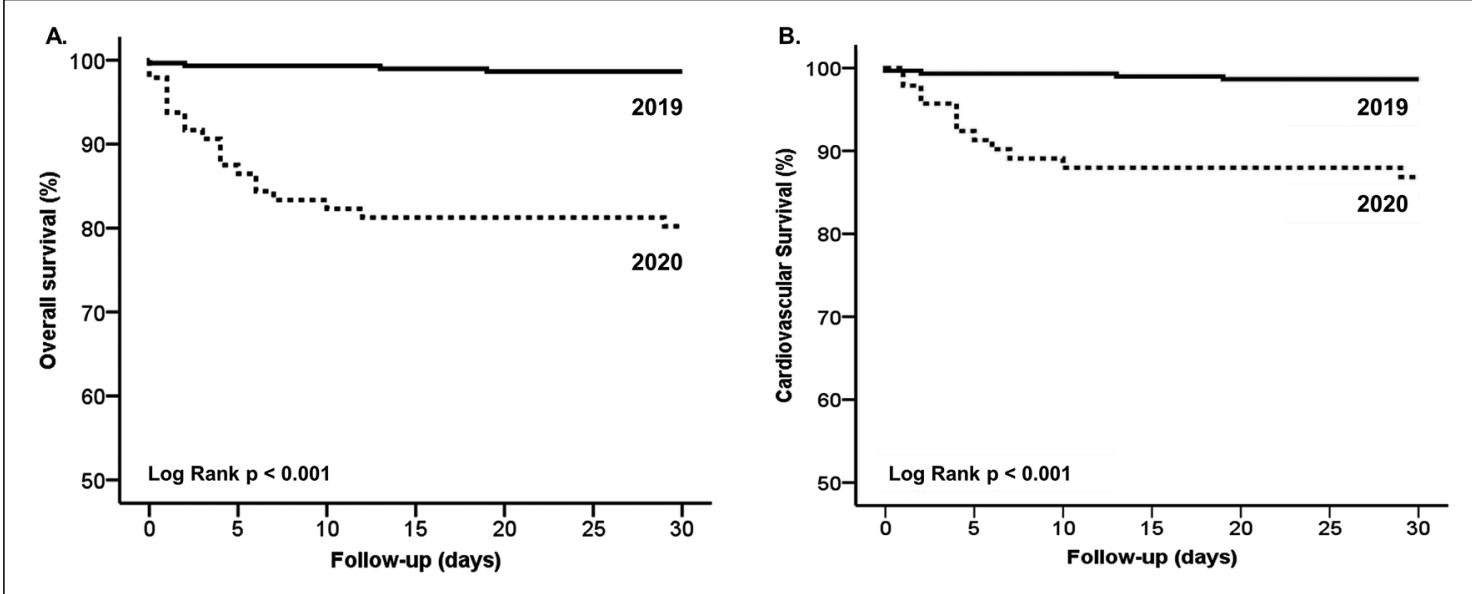

Figure 1.

\section{Differences during the pandemic according to COVID-19 status}

There was no difference regarding demographics and comorbidities according to COVID status (Table 3). NSTEMI was the most prevalent AMI type in $\mathrm{C} 19(\mathrm{P})$ patients $(\mathrm{p}<0.01)$.

At coronary angiography, $\mathrm{C} 19(\mathrm{P})$ patients exhibited intracoronary thrombi more frequently $(\mathrm{p}<0.01)$, and less CAD $(\mathrm{p}=0.005)$. After PCI, TIMI-3 flow was less common in $\mathrm{C} 19(\mathrm{P})$ patients $(\mathrm{p}<0.01) . \mathrm{C} 19(\mathrm{P})$ patients had lower mean LVEF $(\mathrm{p}<0.01)$, more prevalent significant systolic disfunction $(\mathrm{p}<0.01)$, and higher mean high-sensitivity troponin measurements $(\mathrm{p}<0.01)$. Patients with $\mathrm{C} 19(\mathrm{~N})$ status had a greater incidence of CS $(p=0.03)$, while there were no major differences in the incidence of mechanical complications between groups $(\mathrm{p}=0.16)$.
An increase in 30-day mortality was observed in patients with $\mathrm{C} 19(\mathrm{P})(\mathrm{p}=0.018)$ (Figure-1A). Of note, 30-day cardiovascular mortality showed no differences according to COVID-19 status $(p=0.715)$ (Figure-1B). Seven patients died of non-cardiovascular causes, due to COVID-19-related acute respiratory distress syndrome. C19(P) was associated to an increase in the relative risk of overall death at 30-days of follow up (RR 2.9, 95\% CI 1.14-7.36; $\mathrm{p}=0.03$ ) (Table 4). When adjusted by AMI type, $\mathrm{C} 19(\mathrm{P})$ status remained associated to an increased risk of overall mortality at 30days (RR 3.7; 95\% CI 1.4-9.8, p < 0.01). C19(P) status was not associated to an increase in 30-day cardiovascular mortality $(\mathrm{p}=0.72)$. STEMI, CT, significant systolic dysfunction, and CS were predictors of cardiovascular deaths at univariate analyses (Table 4). 


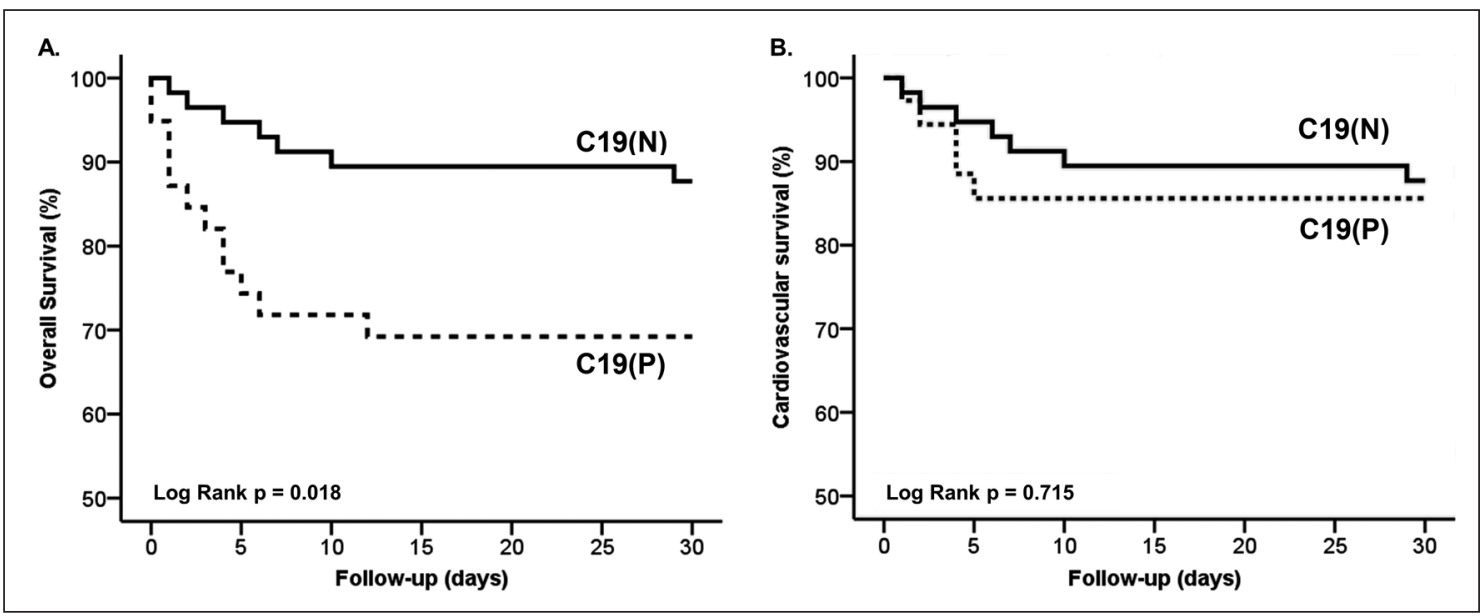

Figure 2.

Table 3. Baseline clinical and periprocedural characteristics and outcomes of patients with AMI according to COVID-19 status during the COVID-19 pandemic

\begin{tabular}{|c|c|c|c|}
\hline & $\begin{array}{l}\text { COVID-19 (-) } \\
(n=57)\end{array}$ & $\begin{array}{c}\text { COVID-19 (+) } \\
(n=39)\end{array}$ & $\mathbf{P}$ \\
\hline Age - years & $61.3 \pm 10.8$ & $64.9 \pm 12.9$ & 0.14 \\
\hline Male - number (\%) & $44(77.2)$ & $25(64.1)$ & 0.16 \\
\hline Hypertension - number (\%) & $40(70.1)$ & $23(59.0)$ & 0.26 \\
\hline Diabetes - number (\%) & $23(40.3)$ & $15(38.4)$ & 0.85 \\
\hline Dyslipidemia - number (\%) & $13(22.8)$ & $7(17.9)$ & 0.57 \\
\hline Smoker - number (\%) & $25(43.9)$ & $13(33.3)$ & 0.30 \\
\hline \multicolumn{4}{|l|}{ Index event } \\
\hline STEMI - number (\%) & $34(59.6)$ & $11(28.2)$ & $<0.01$ \\
\hline Median S-to-FMC time (IQR) - hours* & $6.0(2.0-24.0)$ & $3.0(2.0-10.0)$ & 0.54 \\
\hline STEMI late presentation - number (\%) & $17(50.0)$ & $3(27.3)$ & 0.19 \\
\hline Systemic thrombolysis - number (\%) & $3(8.8)$ & $2(18.1)$ & 0.98 \\
\hline Multivessel disease - number (\%) & $26(45.6)$ & $7(17.9)$ & $<0.01$ \\
\hline Left main coronary disease - number (\%) & $5(8.8)$ & $3(7.7)$ & 0.85 \\
\hline MINOCA & $4(7.0)$ & $25(64.1)$ & $<0.01$ \\
\hline Intracoronary thrombi - number (\%) & $11(19.3)$ & $21(53.8)$ & $<0.01$ \\
\hline Median D-to-D time $(\mathrm{IQR})-$ hours $^{\dagger}$ & $4.0(3.0-11.0)$ & $3.0(1.5-5.0)$ & 0.49 \\
\hline TIMI 3 flow after $\mathrm{PCI}$ - number (\%) & $44(77.2)$ & $7(17.9)$ & $<0.01$ \\
\hline No-reflow - number (\%) & $6(10.5)$ & $8(20.5)$ & 0.17 \\
\hline Cardiogenic shock presentation - number (\%) & $16(28.1)$ & $3(7.7)$ & 0.03 \\
\hline LVEF - \% & $48 \pm 12$ & $43 \pm 14$ & $<0.01$ \\
\hline LVEF $\leq 40 \%-$ number $(\%)$ & $14(24.6)$ & $22(56.4)$ & $<0.01$ \\
\hline Maximal hs-cTnl - pg/ml & $4992 \pm 3467$ & $13012 \pm 9667$ & $<0.01$ \\
\hline \multicolumn{4}{|l|}{ Complications } \\
\hline Overall deaths within 30 days - number (\%) & $7(12.3)$ & $12(30.8)$ & 0.02 \\
\hline CV deaths within 30 days - number (\%) & $7(12.3)$ & $5(12.8)$ & 0.72 \\
\hline Mechanical complications - number (\%) & $8(14.0)$ & $2(5.1)$ & 0.16 \\
\hline
\end{tabular}

*In patients with STEMI. 'In patients with STEMI, excluding thrombolysis. 
Table 4. Univariate analyses for predictors of 30-day overall and cardiovascular mortality in patients with AMI during the COVID-19 pandemic

\begin{tabular}{|lcc|}
\hline Variable & $\begin{array}{c}\text { Overall mortality } \\
\text { Risk ratio } \mathbf{( 9 5 \%} \mathbf{~ C l})\end{array}$ & $\begin{array}{c}\text { CV mortality } \\
\text { Risk ratio } \mathbf{9 5 \%} \text { Cl) }\end{array}$ \\
\hline STEMI & $1.56(0.63-3.87)$ & $12.42(1.60-96.25)$ \\
\hline STEMI late presentation & $2.33(0.68-7.95)$ & $2.33(0.68-7.95)$ \\
\hline MINOCA & $2.36(0.96-5.80)$ & $1.91(0.61-6.02)$ \\
\hline Multivessel disease & $1.60(0.58-4.44)$ & $1.16(0.35-3.85)$ \\
\hline Coronary thrombosis & $3.19(1.28-7.93)$ & $3.32(1.05-10.47)$ \\
COVID-19 positive status & $2.90(1.14-7.36)$ & $1.24(0.39-3.90)$ \\
\hline LVEF $\leq 40 \%$ & $11.18(3.3-38.5)$ & $6.52(1.76-24.14)$ \\
Cardiogenic shock & $15.7(5.6-44.2)$ & $66.2(8.5-518.4)$ \\
\hline
\end{tabular}

\section{Discussion}

We observed a $67.5 \%$ reduction in AMI referrals to our cardiac catheterization laboratory. Prior reports described reductions in admissions for AMI and/or cardiac catheterization laboratory activations for STEMI, ranging between 31 and $53^{7-13}$. The Latin American Society of Interventional Cardiology (SOLACI), compared two week periods before and after quarantine within 2020, reporting a decrease in coronary angiography and PCI for STEMI of 55.7\% and 51.2\%, respectively ${ }^{6}$. Data from Chilean centers showed reductions of coronary angiography for STEMI of $45.3 \%{ }^{6}$. Toro et al. revealed no drops in AMI cases seen at emergency departments during the first two months of the COVID-19 pandemic compared to previous years ${ }^{17}$. Our study considers a longer period of the first pandemic wave in Chile, during which the number of COVID-19 cases increased, large-scale lockdowns were implemented and healthcare system strains ensued ${ }^{18}$.

The decrease in admissions for AMI constitutes a matter of concern. The limited access to early reperfusion and medical treatment will likely result in an increase of cardiovascular mortality. The decrease in AMI consultations could be partially responsible for the rise of out-of-hospital cardiac arrests during the COVID-19 outbreak $^{19-21}$.

In regard to patients transferred for cardiac catheterization for AMI, during the pandemic period we noticed an increase in S-to-FMC and late presentations for STEMI. We also observed a
10 -fold increase in the proportion of patients with S-to-FMC $>24$ hours for NSTEMI. Most studies concerning S-to-FMC suggest an increase in S-toFMC for STEMI. Tam et al, described a significant increase in S-to-FMC for STEMI patients in Hong Kong, with median values of 318 minutes during the pandemic $(\mathrm{n}=7)$ versus 82 minutes prior to the pandemic $(n=108)^{22}$. Wilson et al $(n=388)$, described a 3-fold increase in late presentation for STEMI in London (34.1\% during COVID-19 vs $10.4 \%$ before COVID-19). ${ }^{23}$ Trabattoni et al, reported $41 \%$ of STEMI patients consulting after 24 hours of symptoms-onset compared to $20 \%$ during the prior year ${ }^{24}$. Braiteh et al, described $36.4 \%$ of NSTEMI patients had $>24$ hours of S-to-FMC during the outbreak compared to $27.1 \%$ in 2019 at a single center study in New York $(p=0.03)^{25}$. Primessnig et al, in a single-center study from Germany, described $>20 \%$ increase in STEMI late presentation and NSTEMI S-to-FMC $>24$ hours during the early COVID-19 outbreak ${ }^{26}$.

Fear of infection, delays in medical attention and misled altruism, have been suggested as possible explanations to reduced admissions for AMI, increase in S-to-FMC and late AMI presentations ${ }^{7,27-29}$.

During the COVID-19 outbreak, we observed a significant increase in D-to-D times. No relevant differences regarding $\mathrm{D}$-to-D times have been reported in European and Chinese healthcare centers ${ }^{7,22,30-32}$. In a survey by SOLACI, $58.2 \%$ Latin-American centers signaled delays to reperfusion in STEMI patients ${ }^{6}$. Regional 
differences could be explained by availability of systemic thrombolysis or cardiac catheterization laboratories, and transportation limitations. There were no changes in cardiac catheterization availability for STEMI patients at our center, neither increases in systemic thrombolysis performance in our population during the pandemic period. Delays in D-to-D time in our center were probably secondary to deficiencies in transportation. Preliminary information on ambulance transfers from our Health Service, showed a $4.4 \%$ reduction in overall transfers and $12.8 \%$ reduction in interfacility transfers during COVID-19 outbreak ${ }^{33}$. Possible reasons for transfer decline include limited number of ambulances, personnel shortages and disinfection protocols. No official data regarding ambulance response times was available.

Patients had more severe presentations of AMI during the COVID-19 outbreak, shown by the higher troponin values and greater incidence of significant left ventricular systolic dysfunction. These markers had been previously described by other groups and associated mainly to delays in reperfusion ${ }^{26,29,34}$. Primessnig et al, suggested that an increase in the prevalence of CS was mostly associated to delayed reperfusion therapy for $\mathrm{AMI}^{26}$. In our study, CS was more prevalent in the $\mathrm{C} 19(\mathrm{~N})$ patients, probably due to the higher prevalence of STEMI with delayed reperfusion therapy in this subgroup.

C19(P) patients exhibited a greater incidence of intracoronary thrombi, reduced TIMI flow and a tendency towards no reflow phenomena, probably related to the prothrombotic state induced as part of the inflammatory response to COVID-19. Higher thrombus burden, reduced TIMI flow at procedural ending and increase use of thrombus aspiration devices use have been previously associated to COVID-19 positivity in STEMI patients ${ }^{31,35}$.

We observed an increase in 30-day overall and cardiovascular mortality for AMI during COVID-19 pandemic, similar to AMI mortality rates documented in Chile in the early $1980 \mathrm{~s}^{37}$. Trabattoni et al, described an in-hospital mortality for AMI of 38\% during the COVID-19 outbreak versus $10 \%$ during the same time period in 2019 in Italy ${ }^{24}$. An Italian multicenter study of STEMI patients with $\mathrm{C} 19(\mathrm{P})$ status exhibited greater mortality among STEMI patients $(28.6 \%$ vs $11.9 \%, \mathrm{p}<0.05)^{10}$. A retrospective study in
STEMI patients from pan-London heart attack group, showed C19(P) patients had higher mortality compared to COVID-19 negative patients undergoing primary PCI $(21.7 \%$ vs $9.3 \%$, OR 2.72; 95\% CI 1.25-5.82) $)^{31}$. In our study COVID-19 positivity was an independent predictor of 30-day overall mortality in AMI patients, albeit not of cardiovascular mortality, as half of patients from COVID-19 group experienced deaths related to the development of acute respiratory distress syndrome. Multicentric data from the National Health Service, showed no evident differences of in-hospital mortality of patients admitted for AMI between January and May of 2020 and the same period of $2019^{38}$. Unfortunately, the British studies do not report 30-day overall or cardiovascular mortality rates, and comprise a period with proportionally less new $\mathrm{C} 19(\mathrm{P})$ cases and perhaps less strain towards the healthcare system $^{31,38}$. In the United States, marked increases in cardiovascular mortality due to ischemic heart disease were reported in $\mathrm{C} 19(\mathrm{~N})$ patients in states that experienced the early surges of COVID-19. This was not observed in states with later surges in COVID- 19 cases $^{39}$.

\section{Limitations}

Considering that this is a single-center observational experience, our results may not be generalized to other regions. Following discharge after the procedures performed at the cardiac catheterization laboratory, most patients returned to their referral hospitals to continue monitorization and care. Symptom onset could have been imprecisely reported by patients, and was registered as approximate hours in our registries. Patients with AMI with non-obstructive coronary artery disease underwent intravascular imaging according to operator criteria, and cardiac magnetic resonance was not performed to address COVID-19 associated myocarditis or stress-induced cardiomyopathy as differential diagnosis. Analyses for independent predictors of adverse outcomes could be better addressed through multicentric registries.

\section{Conclusions}

COVID-19 pandemic had detrimental consequences over AMI treatment access and prognosis. During the COVID-19 pandemic we observed a 
reduction in AMI referrals for cardiac catheterization, delays in presentation to medical attention and access to treatment, higher incidence of CS and mechanical complications, and worse survival at 30 days compared to the previous year. C19(P) patients had a greater incidence of NSTEMI, and higher overall and non-cardiovascular mortality associated to the infection. C19(N) patients had a greater incidence of STEMI and CS.

Acknowledgments: We would like to thank to all our team, for the hart work during this time.

\section{References}

1. Departamento de Estadísticas e Información de Salud. Estadísticas de Salud [Internet]. 2018. Available from: https://deis.minsal.cl/estadisticas-de-salud/ [citado el 30 de octubre de 2019].

2. Nazzal C, Alonso F, Cerecera F, Ojeda JM. Tendencia en la sobrevida de pacientes hospitalizados por infarto agudo de miocardio según nivel socioeconómico: Chile, 2002-2012. Rev Med Chile 2017; 145 (7): 827-36.

3. Martínez S A, Nazzal N C, Fajuri N A, Barra L LE, Mayerson G A, Cavada Ch G, et al. Mortalidad post infarto del miocardio en Chile: Comparación de los registros de angioplastía primaria versus trombolisis. Rev Chil Cardiol. 2010; 29 (1): 29-36.

4. ESC Guidance for the Diagnosis and Management of CV Disease during the COVID-19 Pandemic. [Internet]. Available from: https://www.escardio.org/Education/ COVID-19-and-Cardiology/ESC-COVID-19-Guidance [citado el 10 de julio de 2020].

5. Welt FGP, Shah PB, Aronow HD, Bortnick AE, Henry TD, Sherwood MW, et al. Catheterization Laboratory Considerations During the Coronavirus (COVID-19) Pandemic: From the ACC's Interventional Council and SCAI. J Am Coll Cardiol. 2020; 75 (18): 2372-5.

6. Mayol J, Artucio C, Batista I, Puentes A, Villegas J, Quizpe R, et al. An international survey in Latin America on the practice of interventional cardiology during the COVID-19 pandemic, with a particular focus on myocardial infarction. Netherlands Hear J. 2020;28:424-30.

7. Abdelaziz HK, Abdelrahman A, Nabi A, Debski M, Mentias A, Choudhury T, et al. Impact of COVID-19 pandemic on patients with ST-segment elevation myocardial infarction: Insights from a British cardiac center. Am Heart J. 2020; 226: 45-8.

8. García S, Albaghdadi MS, Meraj PM, Schmidt C, Garberich R, Jaffer FA, et al. Reduction in ST-Segment Ele- vation Cardiac Catheterization Laboratory Activations in the United States During COVID-19 Pandemic. J Am Coll Cardiol. 2020; 75 (22): 2871-2.

9. Pessoa-Amorim G, Camm CF, Gajendragadkar P, De Maria GL, Arsac C, Laroche C, et al. Admission of patients with STEMI since the outbreak of the COVID-19 pandemic: a survey by the European Society of Cardiology. Eur Hear journal Qual care Clin outcomes. 2020; 6: 210-6.

10. De Rosa S, Spaccarotella C, Basso C, Calabrò MP, Curcio A, Filardi PP, et al. Reduction of hospitalizations for myocardial infarction in Italy in the COVID-19 era. Eur Heart J. 2020; 41 (22): 2083-8.

11. De Filippo O, D’Ascenzo F, Angelini F, Bocchino PP, Conrotto F, Saglietto A, et al. Reduced rate of hospital admissions for ACS during Covid-19 outbreak in northern Italy. N Engl J Med. 2020; 383: 88-9.

12. Rodríguez-Leor O, Cid-Álvarez B, Ojeda S, Martín-Moreiras J, Ramón Rumoroso J, López-Palop R, et al. Impact of the COVID-19 pandemic on interventional cardiology activity in Spain. REC Interv Cardiol. 2020; 2: 82-9.

13. Lantelme P, Couray Targe S, Metral P, Bochaton T, Ranc S, Le Bourhis Zaimi M, et al. Worrying decrease in hospital admissions for myocardial infarction during the COVID-19 pandemic. Arch Cardiovasc Dis. 2020;113(67):443-7.

14. Thygesen K, Alpert JS, Jaffe AS, Chaitman BR, Bax JJ, Morrow DA, et al. Fourth Universal Definition of Myocardial Infarction (2018). J Am Coll Cardiol. 2018; 72 (18): 2231-64.

15. Sherman CT, Litvack F, Grundfest W, Lee M, Hickey A, Chaux A, et al. Coronary Angioscopy in Patients with Unstable Angina Pectoris. N Engl J Med. 1986; 315 (15): 913-9.

16. García-García HM, McFadden EP, Farb A, Mehran R, Stone GW, Spertus J, et al. Standardized end point definitions for coronary intervention trials: The academic research consortium-2 consensus document. Circulation. 2018;137(24):2635-50.

17. Toro L, Parra A, Alvo M, Toro L, Parra A, Alvo M. Epidemia de COVID-19 en Chile: impacto en atenciones de Servicios de Urgencia y Patologías Específicas. Rev Med Chile 2020; 148 (4): 558-60.

18. Canals M, Cuadrado C, Canals A, Yohannessen K, Lefio LA, Bertoglia MP, et al. Epidemic trends, public health response and health system capacity: the Chilean experience in four months of the COVID-19 pandemic. Rev Panam Salud Publica. 2020; 44: e99.

19. Marijon E, Karam N, Jost D, Perrot D, Frattini B, Derkenne C, et al. Out-of-hospital cardiac arrest during the 
COVID-19 pandemic in Paris, France: a population-based, observational study. Lancet Public Heal. 2020; 5 (8): e437-43.

20. Baldi E, Sechi GM, Mare C, Canevari F, Brancaglione A, Primi R, et al. COVID-19 kills at home: the close relationship between the epidemic and the increase of out-of-hospital cardiac arrests. Eur Heart J. 2020; 41 (32): 3045-54.

21. Mountantonakis SE, Saleh M, Coleman K, Kuvin J, Singh V, Jauhar R, et al. Out-of-hospital Cardiac Arrest and Acute Coronary Syndrome Hospitalizations during the COVID-19 Surge. J Am Coll Cardiol. 2020; 76 (10): 1271-3.

22. Tam CCF, Cheung KS, Lam S, Wong A, Yung A, Sze M, et al. Impact of Coronavirus Disease 2019 (COVID-19) Outbreak on ST-Segment-Elevation Myocardial Infarction Care in Hong Kong, China. Circ Cardiovasc Qual Outcomes. 2020; 13 (4): e006631.

23. Wilson SJ, Connolly MJ, Elghamry Z, Cosgrove C, Firoozi S, Lim P, et al. Effect of the COVID-19 Pandemic on ST-Segment-Elevation Myocardial Infarction Presentations and In-Hospital Outcomes. Circ Cardiovasc Interv. 2020; 13: e009438.

24. Trabattoni D, Montorsi P, Merlino L. Late STEMI and NSTEMI Patients' Emergency Calling in COVID-19 Outbreak. Can J Cardiol. 2020; 36: 1161.e7-1161.e8.

25. Braiteh N, Rehman W ur, Alom M, Skovira V, Breiteh $\mathrm{N}$, Rehman I, et al. Decrease in acute coronary syndrome presentations during the COVID-19 pandemic in upstate New York. Am Heart J. 2020; 226: 147-51.

26. Primessnig U, Pieske BM, Sherif M. Increased mortality and worse cardiac outcome of acute myocardial infarction during the early COVID-19 pandemic. ESC Hear Fail. 2021; 8 (1): 333-43.

27. Roffi M, Guagliumi G, Ibanez B. The obstacle course of reperfusion for ST-segment-elevation myocardial infarction in the COVID-19 pandemic. Circulation. 2020; 141 (24): 1951-3.

28. Brindis RG, Bates ER, Henry TD. Value of registries in ST-segment-elevation myocardial infarction care in both the pre-coronavirus disease 2019 and the coronavirus disease 2019 eras. J Am Heart Assoc. 2021; 10 (1): $1-3$.

29. Hammad TA, Parikh M, Tashtish N, Lowry CM, Gorbey D, Forouzandeh F, et al. Impact of COVID-19 pandemic on ST-elevation myocardial infarction in a non-COVID-19 epicenter. Catheter Cardiovasc Interv. 2020; $97(2)$.
30. Gramegna M, Baldetti L, Beneduce A, Pannone L, Falasconi G, Calvo F, et al. ST-Segment-Elevation Myocardial Infarction During COVID-19 Pandemic: Insights From a Regional Public Service Healthcare Hub. Circ Cardiovasc Interv. 2020; 13: e009413.

31. Little CD, Kotecha T, Candilio L, Jabbour RJ, Collins GB, Ahmed A, et al. COVID-19 pandemic and STEMI : pathway activation and outcomes from London heart attack group. Open Hear. 2020; 7: e001432.

32. Xiang D, Xiang X, Zhang W, Yi S, Zhang J, Gu X, et al. Management and Outcomes of Patients With STEMI During the COVID-19 Pandemic in China. J Am Coll Cardiol. 2020; 76: 1318-24.

33. Ministerio de Salud. Sistema Reportes REM [Internet]. Available from: https://reportesrem.minsal.cl/ [citado el 10 de febrero de 2021].

34. Chew NW, Sia CH, Wee HL, Benedict LJ Da, Rastogi S, Kojodjojo P, et al. Impact of the COVID-19 Pandemic on Door-to-Balloon Time for Primary Percutaneous Coronary Intervention - Results From the Singapore Western STEMI Network. Circ J [Internet]. 2021; 85 (2): 139-49. Available from: https://pubmed.ncbi.nlm. nih.gov/33162491/ [citado el 3 de marzo de 2021].

35. Choudry FA, Hamshere SM, Rathod KS, Akhtar MM, Archbold RA, Guttmann OP, et al. High Thrombus Burden in Patients With COVID-19 Presenting With ST-Segment Elevation Myocardial Infarction. J Am Coll Cardiol [Internet]. 2020; 76 (10): 1168-76. Available from: /pmc/articles/PMC7833185/ [citado el 3 de marzo de 2021].

36. Lauridsen MD, Butt JH, Østergaard L, Møller JE, Hassager C, Gerds T, et al. Incidence of acute myocardial infarction-related cardiogenic shock during corona virus disease 19 (COVID-19) pandemic. IJC Hear Vasc. 2020;31.

37. Almendares C, Corbalán R, Castro P, Rodríguez A, Marchant E, Kunstmann S, et al. [Hospital course of acute myocardial infarction: significance of the therapeutic procedures of early reperfusion]. Rev Med Chile 1995; 123: 1365-71.

38. Mafham MM, Spata E, Goldacre R, Gair D, Curnow P, Bray $\mathrm{M}$, et al. COVID-19 pandemic and admission rates for and management of acute coronary syndromes in England. Lancet. 2020; 396: 381-9.

39. Wadhera RK, Shen C, Gondi S, Chen S, Kazi DS, Yeh RW. Cardiovascular Deaths During the COVID-19 Pandemic in the United States. J Am Coll Cardiol. 2021; 77 (2): 159-69. 